\title{
Lithospheric structure and geodynamic properties of the Tibetan plateau and its adjacent regions*
}

\author{
Junmeng Zhao * \\ Institute of Tibetan Plateau Research, Chinese Academy of Sciences, Beijing 100110, China
}

The Tibetan plateau has an elevation of $4-5 \mathrm{~km}$ above sea level and a crustal thickness of $\sim 80 \mathrm{~km}$ (Zhao et al., 2010d), and its ongoing tectonic evolution is one of the most important Meso-Cenozoic events affecting our planet today. The Tibetan plateau influences global climate, especially in the northern hemisphere, and the structural behavior of the crust and mantle in this region actively controls the development and evolution of the entire geodynamic regime. The Tibetan plateau was generated by continental collision and postcollisional, intra-continental deformation of the Indian and Eurasian plates beginning $\sim 50 \mathrm{Ma}$. Total tectonic shortening between the two plates is estimated to be at least $1000-1400 \mathrm{~km}$, and may be as much as 2000 $3000 \mathrm{~km}$. Although understanding the tectonic processes involved in forming the plateau has attracted the interest of geoscientists from all over the world, the mechanisms by which this shortening has been accommodated is still unknown.

Over the past century, numerous models have been proposed to explain the formation and evolution of the plateau. For example, as early as the 1920s, German scientist Argand (1924) first postulated that the Tibetan plateau formed as a result of collision and post-collision convergence of the Indian subcontinent with Eurasia. This collision resulted in shortening and thickening of the crust to $\sim 80 \mathrm{~km}$, producing the magnificent mountain ranges of the Himalaya, Karakorum, and Tianshan (Figure 1a). This perspective remains widely accepted, but the development of the plateau can also be evaluated within the context of the larger dynamic system related to subduction of oceanic lithosphere beneath eastern Eurasia and Indonesia. Willett and

\footnotetext{
* Received 11 October 2012; accepted in revised form 20 November 2012; published 10 December 2012.

† Corresponding author. e-mail: zhaojm@itpcas.ac.cn

(c) The Seismological Society of China, Institute of Geophysics, China Earthquake Administration, and Springer-Verlag Berlin Heidelberg 2012
}

Beaumont (1994) proposed southward subduction and roll-back of the Asian lithospheric mantle as a process for formation of the Tibetan plateau (Figure 1b). The combined effect of northward subduction of the Indian plate and southward subduction of Asian plate at low angles (Yin and Harrison, 2000), or at high angles (Matte et al., 1996), have also been proposed as the main cause for uplift of the plateau (Figure 1c and Figure 1d, respectively). Tapponnier et al. (2001) proposed a multiple and face-to-face subduction model, which is currently a popular interpretation (Figure 1e).

The large number of differing models that attempt to explain the observed uplift of the Tibetan plateau reflects the vast interest in understanding this important tectonic feature, but the question remains: why are so many models needed to explain the evolution of one plateau? The answer may be as follows. If all of the models are correct, then each model is specific to a particular part of the plateau, which indicates that the uplift mechanism of the Tibetan plateau cannot be manifested by only one 2-D model. If some of these models are not true, then perhaps the data used for setting up these models are not of high enough quality and too many in number. For example, the same low quality seismic data used in two different studies by Kind et al. (2002) and Kumar et al. (2006) resulted in different interpretations (Figure 2a and Figure 2b, respectively). This example emphasizes the pitfalls of low quality data and emphasizes the paramount importance of obtaining higher quality data.

Geophysical explorations in the Qaidam basin were done as early as the 1960s (Zeng and He, 1961) to obtain deep tectonic evidence for the presence of oil and gas reserves. A deep seismic reflection survey was conducted along a transect from Golmud to Ejin Qi (Gao et al., 1995) in northeastern Tibet. The study revealed detailed structures, and a geodynamic model has been developed. Another four global geoscience transects have recently 

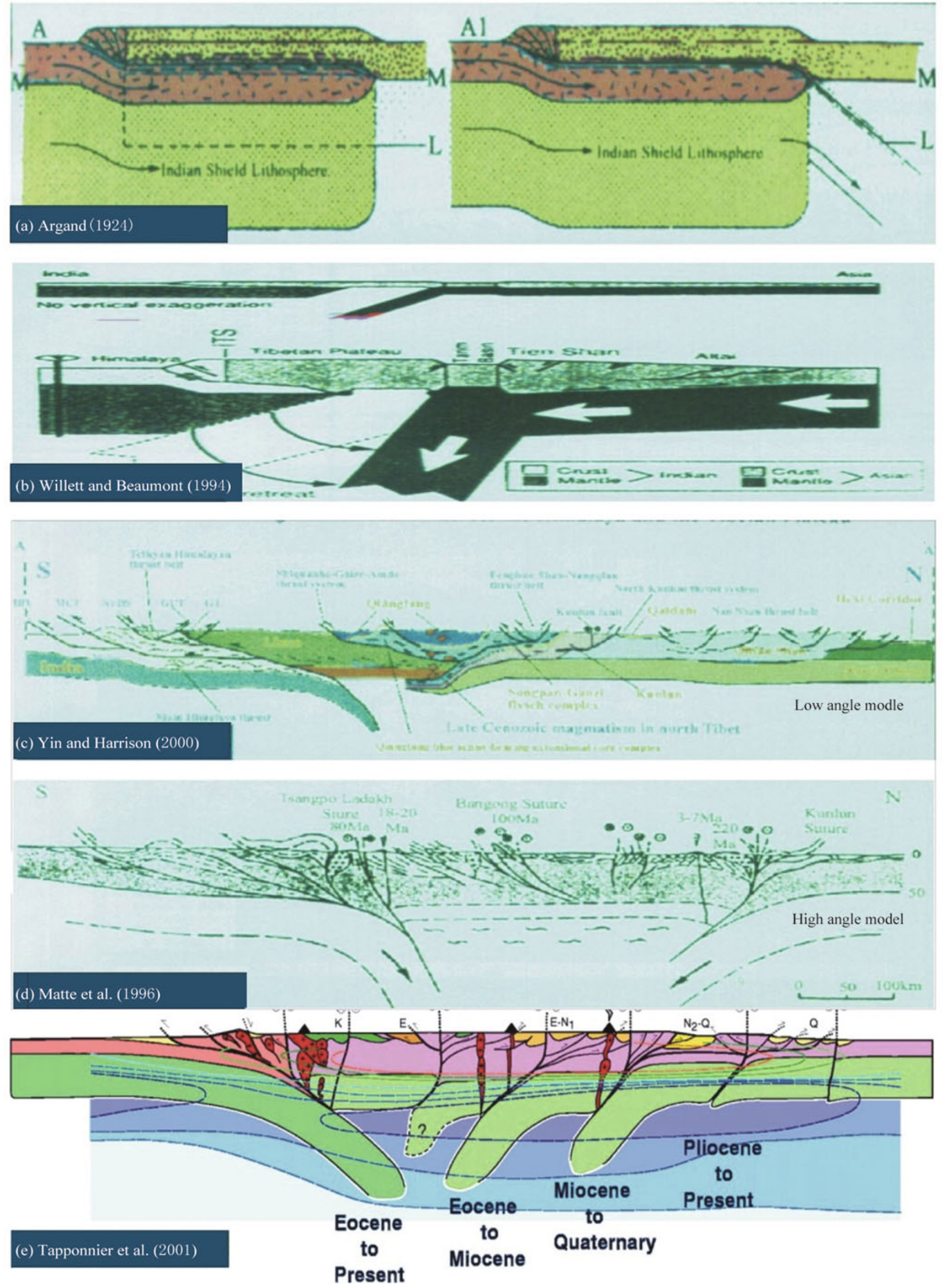

Figure 1 Examples of proposed geodynamic models for the mechanism of Tibetan Plateau uplift. 


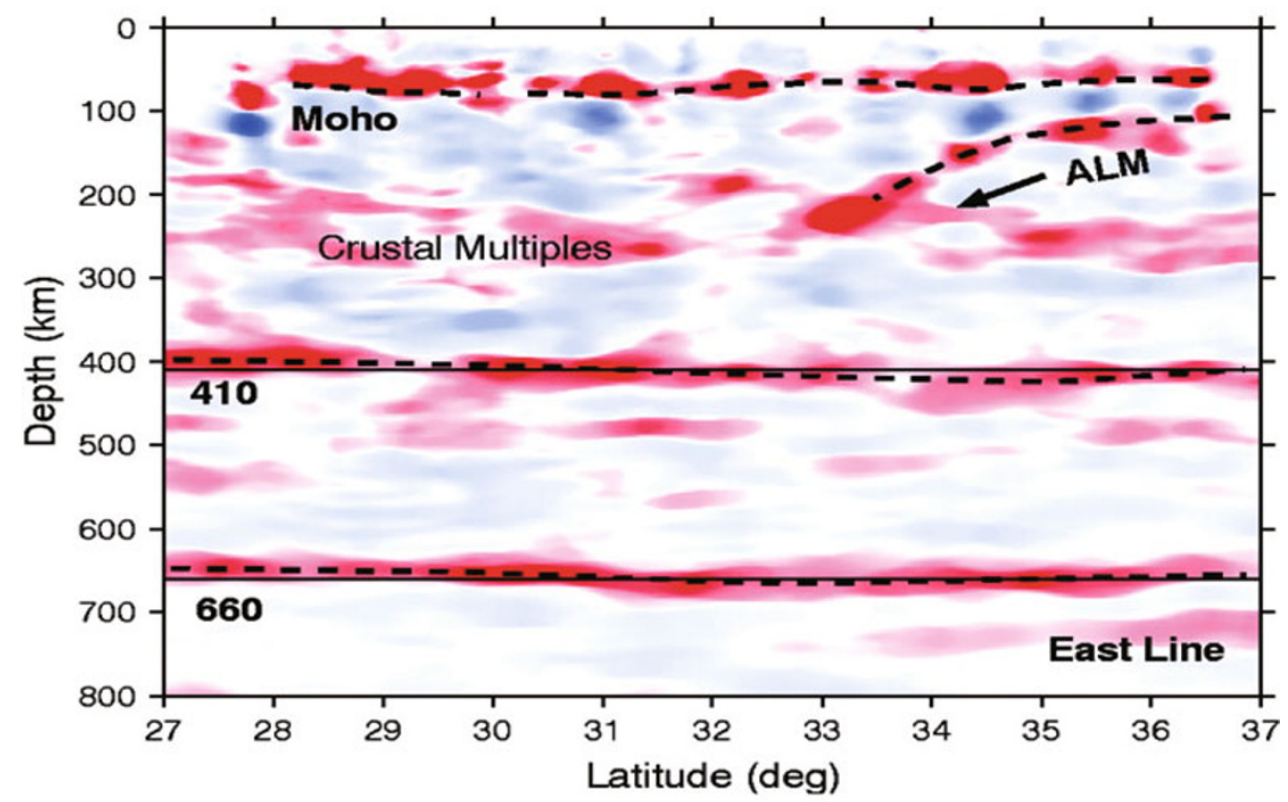

(a)

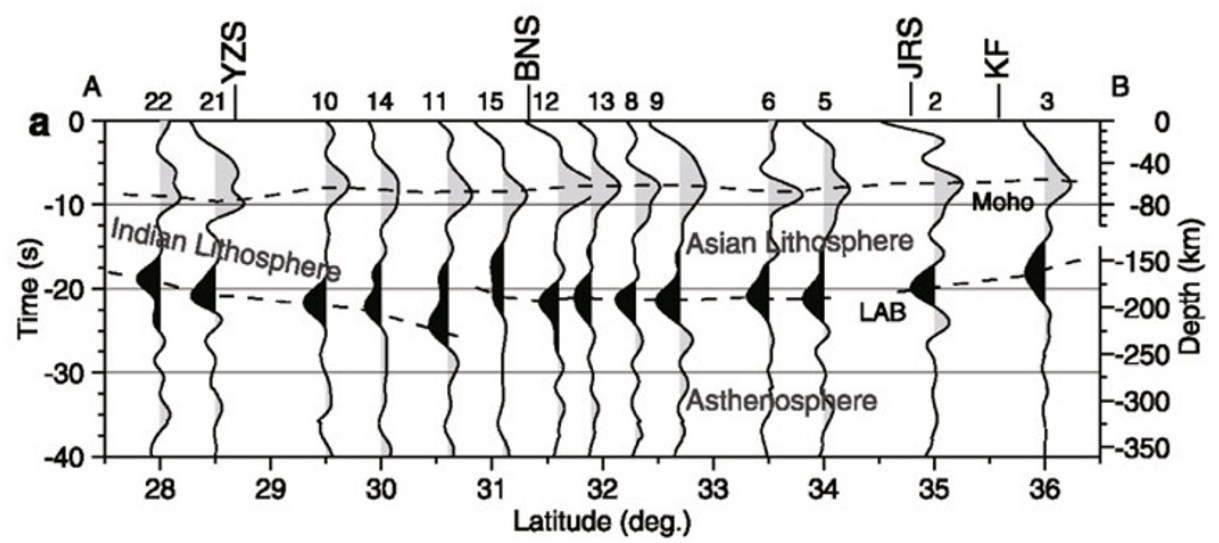

(b)

Figure 2 Crust and mantle structure along the east line by Kind et al. (2002).

been completed across the basin and range province of northwestern China. These transects include surveys from: Xayar to Burqin (Zhao et al., 2003), Emin to Hami (Zhao et al., 2010a), Fuyun to Korla (Zhao et al., 2010c), and Baicheng to Da Qaidam (Zhao et al., 2010b) (Figure 3). The transect from Baicheng to Da Qaidam crosses northern Tibet and reveals a tectonical contact relationship among the Tarim basin, the Altyn Tagh range and the Qaidam basin (Zhao et al., 2006a, 2010b). The main results of the transect from Baicheng to Da Qaidam (Zhao et al., 2006a) have been compiled into the well-known Treatise on Geophysics (Romanowicz and Dziewonski, 2007). The results mentioned above provide some geodynamic conditions for constraining the uplift mechanism of the Tibetan plateau along its northern margin (Zhao, 2012).
The profile from Baicheng to Da Qaidam is a seismic refraction/wide-angle-reflection profile across the Altyn Tagh range and its adjacent basins (Zhao et al., 2006a). The crustal velocity structure, and by inference, the composition of the crust, changes abruptly beneath the Qarqan fault, which is $\sim 100 \mathrm{~km}$ north of the northern margin of the Tibetan plateau. Beneath the Tarim basin north of the Qarqan fault, a platform-type crust is evident. In contrast, south the Qarqan fault, the crustal profile appears to be missing high-velocity lower-crustal layer. This seismic model indicates that the high topography $(\sim 3 \mathrm{~km})$ of the Altyn Tagh range is supported by a wedge-shaped region with a seismic velocity of 7.6$7.8 \mathrm{~km} / \mathrm{s}$ that we interpret as a zone of crust-mantle mixing. We infer that the Altyn Tagh range formed by crustal-scale strike-slip motion along the North Altyn 
Tagh fault and northeast-southwest contraction over the length of the range. The contraction is accommodated by (1) crustal thickening via upper-crustal thrusting and lower-crustal flow (i.e., creep), and (2) slip-parallel (SW-directed) under-thrusting of only the lower crust and mantle of the eastern Tarim basin beneath the Altyn Tagh range.

Across the Qaidam basin we have finished two wide-angle reflection/refraction profiles: the profile from Baicheng to Da Qaidam (Zhao et al., 2006a, 2010b) and the profile from Golmud to Huahaizi. Together, these two profiles reveal that the top surface of the crystalline basement of the Qaidam basin is concave, while the Moho is convex. The lithospheric structure in the southern part of the basin is different from that in the north. Specifically, in the south, differences in velocity and structure are mainly found in the lower crust and the top part of the upper mantle, whereas to the north, differences in density and geomagnetic intensity occur in the lower crust and upper mantle, and in the middle and upper crust, respectively (Zhao et al., 2006b).

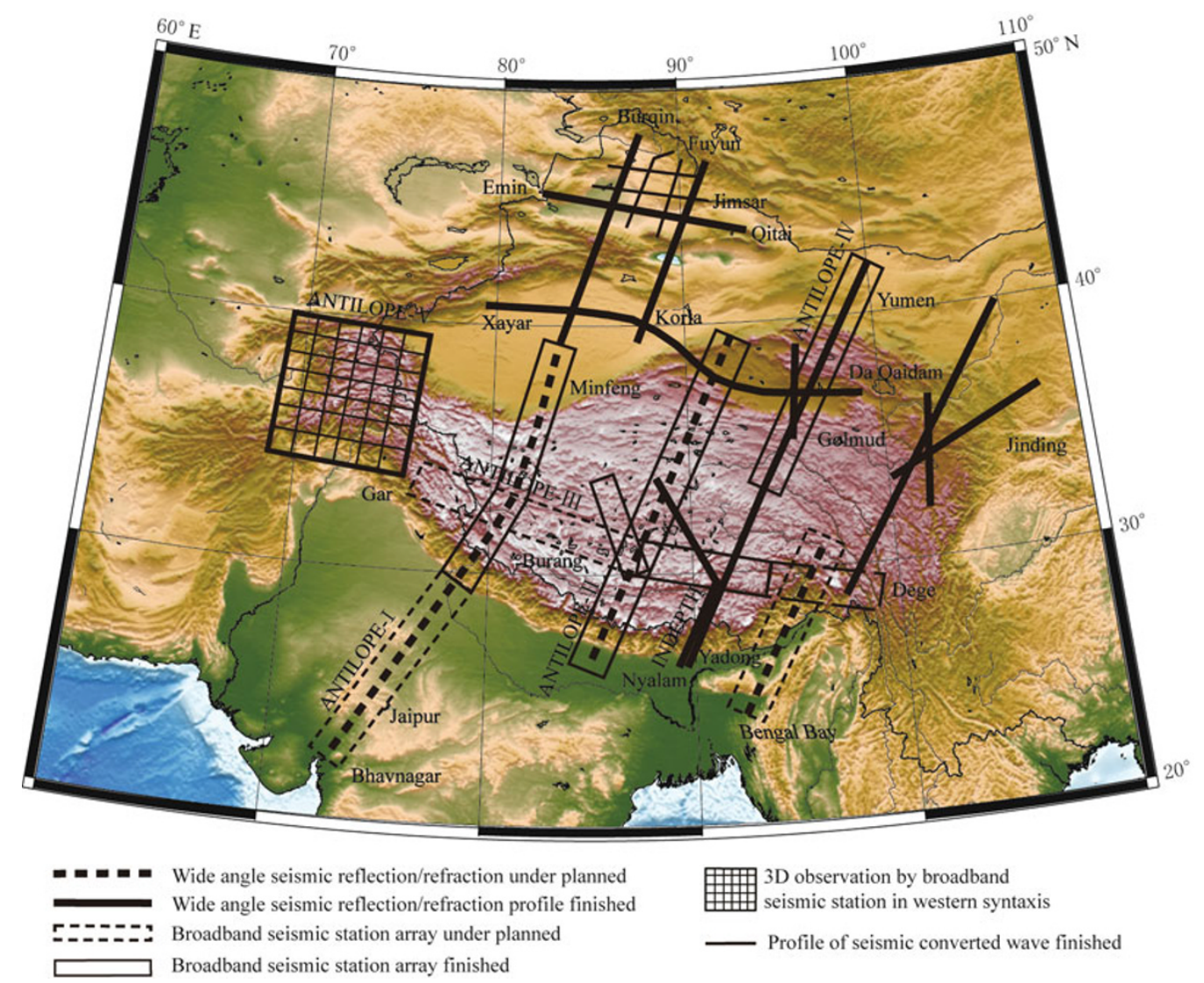

Figure 3 ANTILOPE (Array Network of Tibetan International Lithospheric Observation and Probe Experiments).

The Tibetan plateau is an ideal natural laboratory for geodynamic investigations, and it has been utilized in many geology, geophysical and geochemical studies over the past few decades, yielding a great number of important results, including some break-through geophysical findings regarding the formation and evolution of the plateau. The northern margin of the subducting Indian plate beneath the Tibet, the tectonic pattern and differential features of the crust and upper mantle on both sides of the Yarlung Zangbo suture (YZS) have been identified by a seismic profile from Zhangmu to
Cuoqin located in western Tibet. Results from a magnetotelluric (MT) sounding profile across the Yarlung Zangbo suture in western Tibet suggest that the Indian crust does not cross over the Yarlung Zangbo suture.

Numerous deep seismic reflection studies have recently been carried out in Tibet. Combined with other geophysical work using passive source seismology, these studies reveal the detailed structure of the crust and upper-most mantle.

One of the most successful examples of international cooperation in Tibet is the INDEPTH (Inter- 
national Deep Profiling of Tibet and the Himalayas) project, which was started in 1992. The cooperation has been prolifically successful utilizing multiple methodologies to solve problems, and has been ongoing research projects under INDEPTH-IV.

INDEPTH-I discovered a bottom interface of a detachment zone, along which the lithospheric mantle of the Indian continent is under-thrusted beneath the Himalaya. This research revealed with great detail the relation between subduction and extensional faulting of the high Himalaya (southern Tibet detachment system), and obtained near vertical reflection from the deepest discovered Moho in the world (Zhao et al., 1993; Makovsky et al., 1996; Wu et al., 1998).

INDEPTH-II used comprehensive geophysical exploration techniques, such as near vertical reflection (Brown et al., 1996), seismic wide angle reflection/refraction (Makovsky et al., 1996; Makovsky and Klemperer, 1999), magnetotelluric sounding (MT) (Chen et al., 1996) and broadband seismic surveying (Kind et al., 1996; Yuan et al., 1998). A joint constraint method has been used in data processing and interpretation. The results present some constraints on the crustal shortening caused by a collision between the two continents (Makovsky and Klemperer, 1999), and present some new evidence for the starting time of extension. INDEPTH-II also discovered some evidence for the existence of liquid (partial melt) in the middle crust of southern Tibet (Brown et al., 1996; Makovsky et al., 1996; Wei et al., 2001), and highlighted the importance of lower crustal flow during the plateau formation processes (Nelson et al., 1996; Clark and Royden, 2000; Beaumont et al., 2001).

INDEPTH-III was focused mainly on mantle structure beneath the plateau. It was designed to complete a broadband seismic profile from the northern part of the Lhasa terrain to the Qiangtang terrain across the Bangong-Nujiang suture. Along the profile, a joint observation of active seismology with passive source seismology was carried out, and refraction data from the crust have been obtained (Zhao et al., 2001; Haines et al., 2003). As a result, P- and S-wave velocity models in the central plateau have been obtained from seismic sections from both active passive source methods (Zhao et al., 2001; Haines et al., 2003). The Pn velocity in southern Tibet is different from northern Tibet (Hearn et al., 2001), and mantle anisotropy and P-wave velocities also appear to be different (Tilmann et al., 2003). In addition, the differences in the lithospheric velocity structures in southern and northern Tibet as well as evidence for the existence of a high conductivity layer in the lower crust along the profile were obtained. This research indicates that earthquake activity in central Tibet usually occurs in the top layer of the crust and that the upper mantle transitional zone has not been breached, suggesting that the tectonic activity was limited to depths above $410 \mathrm{~km}$.

INDEPTH-IV focused on an active-source survey of northern Tibet, using a 2-D seismic array composed of 48 broadband stations to investigate geodynamic questions in northern Tibet (Zhao et al., 2011). This research has suggested that in the central and northern part of Tibet, a relatively thin but independent Tibetan lithosphere is present above a flat and southward subducting Asian lithosphere. In addition, the Tibet-Himalaya system appears to be composed of Indian, Tibetan, and Asian lithospheres. In southern Tibet, the Indian lithosphere subducts beneath the Tibetan lithosphere, with its frontier reaching just to the north of the Yarlung Zangbo suture. In the middle and northern parts of the plateau, Asian lithosphere subducts southward beneath the Tibetan lithosphere. North of the Kunlun faults, a formal cratonic lithosphere-asthenosphere boundary (LAB) is observed, similar to the Indian LAB. Due to the lack of data north of the Kunlun faults, the behavior of the Asian lithosphere and northward extension mechanism are unknown (Zhao et al., 2011).

Hi-CLIMB (Himalayan-Tibetan continental lithosphere during mountain building) is another international cooperation research project, which was started in 2002. In order to obtain a high resolution, continuous cross section across the Himalaya, a densely-distributed seismic array (with 270 observation points) was established. Data from the array have revealed a clear Moho discontinuities in upper mantle, and the detailed structure of the main Himalaya thrust (MHT) at depth. The results indicate that the Indian crust currently underthrusts northward beneath the Asian crust, with its lower part subducting beneath the Qiangtang terrain when passing through the Bangong-Nujiang suture.

When the Institute of Tibetan Plateau, Chinese Academy of Sciences was established, we proposed and carried out an international cooperation program, called the ANTILOPE (Array Network of Tibetan International Lithospheric Observation and Probe Experiments). At the present day, we have finished ANTILOPE-I, II, III. Based on the results of ANTILOPE-I and ANTILOPE-II, and combined with a TK profile (a profile from Tianshan to Karakum) (Ku- 
mar et al., 2005) and an LMS profile (a profile across Longmenshan mountain) (Zhang et al., 2010), we have set up a 3-D model for the mechanism for Tibetan plateau uplift (Zhao et al., 2010d). The main points are as followings:

1) Crustal shortening in southern Tibet is accommodated by underthrusting of the Indian crust below the Asian crust that may reach as far north of the YZS. In northern Tibet, crustal shortening is accommodated by homogeneous crustal thickening.

2) The boundary between the Indian and Asian lithospheres below Tibet runs roughly from the western Tarim basin to the eastern Himalayan syntaxis.

3) A discrete lithospheric region was formed in northern and eastern Tibet as a crush zone between the two colliding plates, the existence of which is marked by high temperature, low mantle seismic velocity, poor Sn propagation, east and southeast oriented displacements, and larger seismic (SKS) anisotropy.

4) High, rugged topography is found in western Tibet, and can be supported by the rigid mantle lithosphere below, whereas the lithosphere to the east is weaker due to the existence of the crush zone.

In addition, the research discussed above has allowed us to locate the boundary between the Indian plate and the Asian plate beneath the Tibetan plateau, which has led to a new interpretation that the plateau is composed of three tectonic plates: the Indian plate to the south, the Asian plate to the north, and the Tibetan plate sandwiched between the two (Zhao et al., 2010d). These results raise several new and more challengeable questions:

1) In southern Tibet, the Moho has not been offset, and the Indian plate is currently subducting northward beneath the Tibetan plate along the Himalayan thrust zone. The front of the subducting Indian plate lies approximately along a line from the southwestern margin of the Tarim basin to the eastern syntaxis of the Himalayan orogenic belt. In northern Tibet (Altyn fault), the Moho is offset by $\sim 20 \mathrm{~km}$, suggesting that the crustal shortening here is mainly caused by pure shear and thickening, and no obvious subduction has been found (Zhu and Helmberger, 1998). In northeastern Tibet, the Asian plate is subducting beneath the Tibetan plate, and extends southward to the south of the Jinshajiang suture. The Moho at Kunlunshan has been offset by $\sim 20 \mathrm{~km}$, indicating that strike-slip tectonics may be the dominant style of deformation. Several fundamental questions exist: Where does the Asian plate beneath the Tibetan plate subduct? Did subduction occur in single or multiple phases? How does the Asian lithosphere mantle behave?

2) The Cenozoic regional tectonic features of northern Tibet are mainly controlled by the combined activity of the two strike-slip fault systems - the Kunlun and Altyn Tagh fault systems. The Qilianshan is considered to be an area of pressure deformation and uplift. There are two points of view about the vertical uplift and horizontal extension of the Qilianshan. One school of thought is that the uplift of the Qilianshan was caused by northeastward strike-slip motion along the Altyn Tagh fault, forming a detachment interface in the middle and lower crust. The upper crust thrusts and uplifts along the detachment surface, forming first the southern Qilianshan, then the middle Qilianshan and northern Qilianshan, respectively. We find continuous northeastward strike-slip along the Altyn Tagh fault, and the detachment surface extends northeastward. If this model is true, the deformation intensity and uplift height will be reduced northeastward, forming a detachment surface in the middle and lower crust. This would lead to the Asian mantle lithosphere being underthrust beneath the southern Qilianshan, causing the early Paleo-Asian lithosphere to be completely replaced (Figure 4).

A competing school of thought suggests that northeastward strike-slip would not lead to a detachment in the middle and lower crust of the Qilianshan, and instead would cause regional compression, shortening, and uplift. In this model, the blocks that formed the Qilianshan collected early and have not been broken, but only reactivated along former sutures. If this model is correct, the southern, middle and northern Qilianshan should uplift together at the same time, with few differences in amplitude. The early Asian lithospheric mantle is there, and the Asian lithospheric mantle did not subduct beneath the Qilianshan (Figure 5). This raises several important questions. In what way does the Tibetan plateau extend northeastward? What is its deep dynamic mechanism?

Although a significant amount of geophysical observations have been made in northern Tibet by geoscientists, both domestic and overseas, low-density arrays (station-spacing of $\sim 50 \mathrm{~km}$ ) cannot reveal the detailed and complicated deep structure of the region. Not to mention that the Qilianshan is almost an empty area of seismic prospecting, due to a constraint from natural and humanistic conditions. 


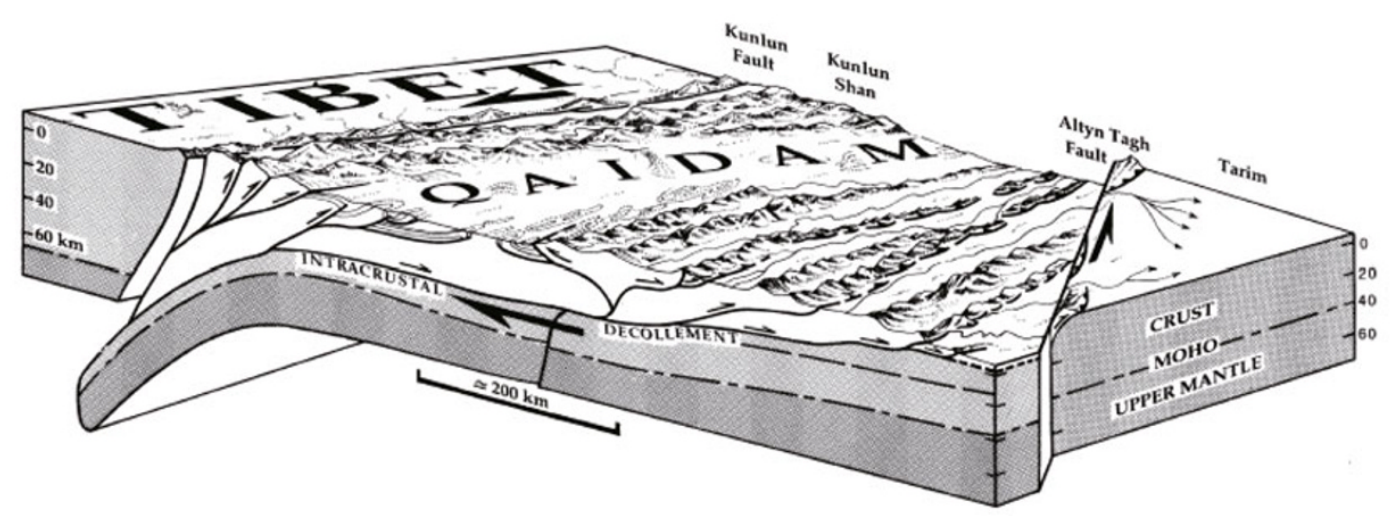

Figure 4 Detachment of the middle and lower crust-A model of gradual progress and uplift (Tapponnier et al., 1990; Meyer et al., 1998).

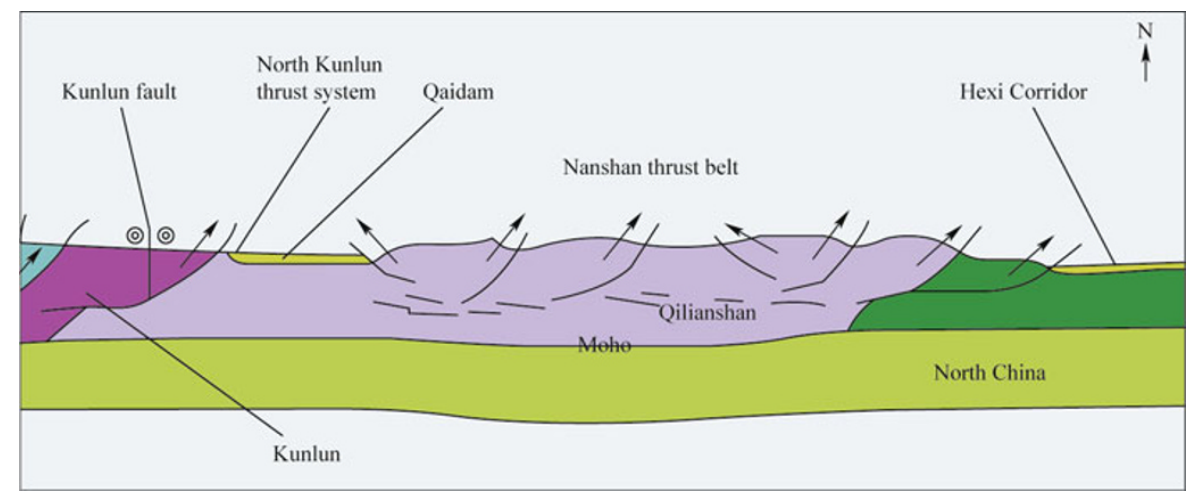

Figure 5 Block collage-late sync uplift model.

Based on the scientific questions mentioned above, we are carrying out the ANTILOPE-IV, a comprehensive 500-km long profile in northeastern Tibet (Figure 6). It starts at the northern part of the Hoh Xil crossing the Kunlunshan, Qaidan basin, Qilianshan, and ends south of the Alxa basin. Along the profile, passive seismology and MT sounding will be carried out to obtain a detailed velocity structure and electricity structure of the crust and mantle. By comprehensive analysis, combining geology with geochemistry, we will try to answer the following questions: How does the Asian lithospheric mantle behave beneath the Asian lithosphere? Where does the Asian plate beneath the Tibetan plate begin to subduct? Was deformation the result of a single or multiple phases of subduction? In what way does the Tibetan plateau extend northeastward? What are the geophysical properties of the plateau at depth?

Composed of 100 stations, the profile crosses the southern part of the Alax basin, the Qilianshan, the Qaidam basin, the eastern Kunlunshan, and the northern part of the Hoh Xil basin. At each station, seis- mic observations and MT sounding will be jointly conducted. This comprehensive profile promises to provide a detailed structural analysis of the crust and mantle for geodynamic research. Additionally, the detailed structure of the crust and mantle can provide some important evidence for research on the mechanisms of seismic development and evolution. In addition, these results can be used for resource, mineral, and petroleum exploration.

The Tibetan plateau demonstrates a record of drifting, colliding and a finally coalescing of different tectonic blocks since the break-up of the Gondwanan supercontinent. Discussion of the uplift and extension of the plateau needs not only the consideration of collision between Indian plate and Eurasian plate, but also the exchange of material and energy at depth. In this research, geophysicists are tasked with extracting intrinsic response, connecting the geologic framework and chemical element distribution with the physics, dynamic mechanism and deep tectonic processes. Subsequently, the vertical uplift and horizontal extension of 

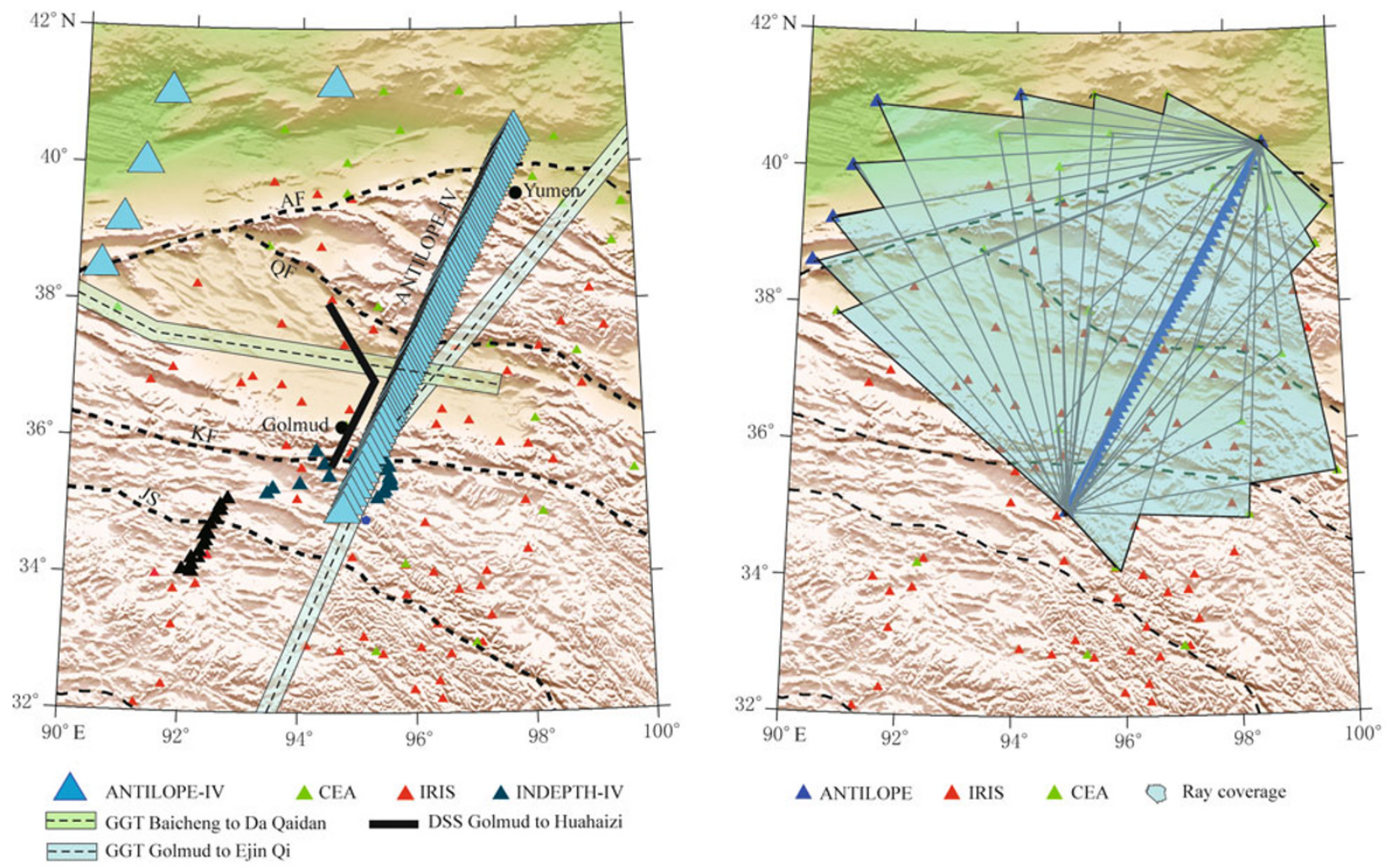

Figure 6 Geological setting and location of the ANTILOPE-IV (left) and the ray coverage for ambient noise tomography (right). In the left panel, AF, QF, KF and JS represent Altyn Tagh fault, Qaidam north marginal fault, Kunlun fault and Jinshajiang suture, respectively.

the plateau and their links to environmental resources, energy sources, and seismic hazard can be made within the kinematic and dynamic regime.

To fit in with a feature of complicated deep structures, processes and multiple force actions in northeastern Tibet, innovations in methodology and theory must be made. In addition new scientific theses, arguments and coupling of theoretical systems with scientific connotation full of creativity are needed.

In order to introduce the latest research into the deep structure and geodynamics of the Tibetan plateau and its adjacent regions, and promote geophysical prospecting and geodynamic study of the Tibet, we have compiled numerous papers dealing with the plateau, from which 16 papers were chosen to form this special issue.

I would like to express my sincere thanks to all the authors for their great contributions, as well as the reviewers for their careful evaluations, opinions, and suggestions to these papers. I would like also to express my thanks to Lili Tian and Jiangli Liu, the editors who have taken great effort and special patience in organizing and publishing this special issue.

\section{References}

Argand E (1924). La tectonique de l'Asie. In: Proceedings of the 13th International Geological Congress. 7: 171-372.

Beaumont C, Jamieson R A, Nguyen M H and Lee B (2001). Himalayan tectonics explained by extrusion of a lowviscosity crustal channel coupled to focused surface denudation. Nature 414: 738-742.

Brown L D, Zhao W, Nelson K D, Hauck M, Alsdorf D, Ross A, Cogan M, Clark M, Liu X and Che J (1996). Bright spots, structure and magmatism in southern Tibet from INDEPTH seismic reflection profiling. Science 274: 1 688-1 690.

Chen L, Booker J R, Jones A G, Wu N, Unsworth M J, Wei W and Tan H (1996). Electrically conductive crust in southern Tibet from INDEPTH magnetotelluric surveying. Science 274: 1 694-1 696.

Clark M K and Royden L H (2000). Topographic ooze: building the eastern margin of Tibet by lower crustal flow. Geology 28: 703-706.

Gao R, Cheng X Z and Ding Q (1995). The primary study of the geodynamic model of the geoscience transect from Golmud to Ejin Qi. Chinese J Geophys 38(Suppl. II): 
3-14 (in Chinese with English abstract).

Haines S, Klemperer S L, Brown L, Guo J, Mechie J, Meissner R, Nelson K D, Ross A and Zhao W (2003). Crustal thickening processes in central Tibet: implications of INDEPTH III seismic data. Tectonics 22: 1-18.

Hearn T, Xiao X, Ni J, Zhao W and INDEPTH-III Seismic Team (2001). Pn velocity beneath central Tibet. EOS Trans $A G U$ 81(48): T51F-12.

Kind R, Ni J, Zhao W, Wu J X, Yuan Y H, Zhao L S, Sandvol E, Reese C, Nabelek J and Hearn T (1996). Evidence from earthquake data for a partially molten crustal layer in southern Tibet. Science 274: 1 692-1 694.

Kind R, Yuan X, Saul J, Nelson D, Sobolev S V, Mechie J, Zhao W, Kosarev G, Ni J, Achauer U and Jiang M (2002). Seismic images of crust and upper mantle beneath Tibet: Evidence for Eurasian plate subduction. Science 298: 1 219-1 221.

Kumar P, Yuan X, Kind R and Kosarev G (2005). The lithosphere-asthenosphere boundary in the Tien ShanKarakoram region from S receiver functions: Evidence for continental subduction. Geophys Res Lett 32(7), doi:10.1029/2004GL022291.

Kumar P, Yuan X, Kind R and Ni J (2006). Imaging the colliding Indian and Asian lithospheric plates beneath Tibet. $J$ Geophys Res 111(B6), doi:10.1029/2005JB003930.

Makovsky Y and Klemperer S (1999). Measuring the seismic properties of Tibetan bright spots: Evidence for free aqueous fluids in the Tibetan middle crust. J Geophys Res 104: 10 795-10 825.

Makovsky Y, Klemperer S L, Huang L and Lu D (1996). Structural elements of the southern Tethyan Himalaya crust from wide-angle seismic data. Tectonics 15: 9971005.

Matte Ph, Tapponnier P, Arnaud N, Bourjot L, Avouac J P, Vidal Ph, Liu Q, Pan Y S and Wang Y (1996). Tectonics of western Tibet, between the Tarim and Indus. Earth Planet Sci Lett 142(3-4): 311-330.

Meyer B, Tapponnier P, Bourjot L, Metivier F, Gaudemer Y, Peltzer G, Guo S M and Chen Z T (1998). Crustal thickening in Gansu-Qinghai, lithospheric mantle subduction, and oblique, strike-slip controlled growth of the Tibet plateau. Geophys J Int 135: 1-47.

Nelson K D, Zhao W J, Brown L D, Kuo J, Che J K, Liu X W, Klemperer S L, Makovsky Y, Meissner R, Mechie J, Kind R, Wenzel F, Ni J, Nabelek J, Chen L S, Tan H D, Wei W B, Jones A G, Booker J, Unsworth M, Kidd W S F, Hauck M, Alsdorf D, Ross A, Cogan M, Wu C D, Sandvol E and Edwards M (1996). Partially molten middle crust beneath southern Tibet: Synthesisof Project INDEPTH results. Science 274: 1 684-1 688.

Romanowicz B A and Dziewonski A M (2007). Seismology and Structure of the Earth: Treatise on Geophysics. Volume I. Elsevier, Amsterdam, 368-370.
Tapponnier P, Meyer B, Avouac J P, Peltzer G, Gaudemer Y, Guo S M, Xiang H F, Yin K L, Chen Z T, Chen S H and Dai H G (1990). Active thrusting and folding in the Qilian Shan, and decoupling between upper crust and mantle in northeastern Tibet. Earth Planet Sci Lett $\mathbf{9 7}$ : 382-403.

Tapponnier P, Xu Z Q, Roger F, Meyer B, Arnaud N, Wittlinger G and Yang J (2001). Oblique stepwise rise and growth of the Tibet plateau. Science 294(23): 1 6711677 .

Tilmann F, Ni J and INDEPTH III Seismic Team (2003). Seismic imaging of the downwelling Indian lithosphere beneath central Tibet. Science 300: 1 424-1 427.

Wei W, Unsworth M, Jones A, Booker J, Tan H, Nelson K D, Chen L, Li S, Solon K, Bedrosian P, Jin S, Deng M, Ledo J, Kay D and Roberts B (2001). Detection of widespread fluids in the Tibetan crust by magnetotelluric studies. Science 292: 716-718.

Willett S D and Beaumont C (1994). Subduction of Asian lithospheric mantle beneath Tibet inferred from models of continental collision. Nature 369: 642-645.

Wu C, Nelson K D, Wortman G, Samson S D, Yue Y, Li J, Kidd W S F and Edwards M A (1998). Yadong cross structure and South Tibetan detachment in the east central Himalaya $\left(89^{\circ}-90^{\circ} \mathrm{E}\right)$. Tectonics 17: 28-45.

Yin A and Harrison T M (2000). Geologic evolution of the Himalayan-Tibetan orogen. Ann Rev Earth Plan Sci 28: $211-280$.

Yuan X, Ni J, Kind R, Mechie J and Sandvol E (1998). Lithospheric and uppermantle structure of southern Tibet from seismological passive source experiment. $J$ Geophys Res 102: 27 491-27 500.

Zeng R S and He C D (1961). Refraction and multiples in low frequency seismic exploration of the Qaidam basin. Chinese J Geophys 10(1): 39-53 (in Chinese).

Zhang Z, Yuan, X, Chen Y, Tian X, Kind R, Li X and Teng J (2010). Seismic signature of the collision between the east Tibetan escape flow and the Sichuan basin. Earth Planet Sci Lett 292: 254-264.

Zhao J M (2005). Lithospheric Structure and Geodynamic Processes of the Tianshan Orogenic Belt. Seismological Press, Beijing, 251pp (in Chinese with English abstract).

Zhao J M (2012). Geodynamic Conditions for Northern Margin of Tibetan Plateau. Science Press, Beijing, 324 (in Chinese).

Zhao J M, Chen X F and Liu X (2010a). A Geoscience Transect from Emin to Hami, Xinjiang, China (including a map of $G G T)$. Science Press, Beijing, 1-53.

Zhao J M, Jin Z J and Liu X (2010b). A Geoscience Transect from Beicheng, Xinjiang to Da Qaidam, Qinghai, China (including a map of GGT). Science Press, Beijing, 1-73.

Zhao J M, Liu G D, Lu Z X, Zhang X K and Zhao G Z (2003). Lithospheric structure and dynamic processes of the Tianshan orogenic belt and the Junggar basin. 
Tectonophysics 376: 199-239.

Zhao J M, Liu X and Wang Q C (2010c). A Geoscience Transect from Fuyun to Korla, Xinjiang, China (including a map of $G G T)$. Science Press, Beijing, 1-87.

Zhao J M, Mooney W D, Zhang X K, Li Z C, Jin Z J and Okaya N (2006a). Crustal structure across the Altyn Tagh Range at the northern margin of the Tibetan plateau and tectonic implications. Earth Planet Sci Lett 241: 804-814.

Zhao J M, Tang W, Lei Y S, Yao C L, Zhang J, Wang W and Huang Y (2006b). The density and geomagnetic intensity of the lithosphere at the northern margin of the Tibetan Plateau. Geoscience Frontiers 13(5): 391-400.

Zhao J M, Yuan X H, Liu H B, Kumar P, Pei S P, Kind R, Zhang Z J, Teng J W, Ding L, Gao X, Xu Q and Wang W (2010d). The boundary between the Indian and Asian plates below Tibet. PNAS 107(25): 11 229-11 233.
Zhao W, Kumar P, Mechie J, Kind R, Meissner R, Wu Z H, Shi D N, Su H P, Xue G Q, Karplus M and Tilmann F (2011). Tibetan plate overriding the Asian plate in central and northern Tibet Nature Geoscience 4: 870-873, doi:10.1038/ngeo1309.

Zhao W, Mechie J, Brown L, Guo J, Haines S, Hearn T, Klemperer S, Ma Y, Meissner R, Nelson K D, Ni J, Pananont P, Rapine R, Ross A and Saul J (2001). Crustal structure of central Tibet as derived from project INDEPTH wide-angle seismic data. Geophys J Int 145: 486-498.

Zhao W, Nelson K D and Project INDEPTH Team (1993). Deep seismic reflection evidence for continental underthrusting beneath southern Tibet. Nature 366: 557-559.

Zhu L and Helmberger D W (1998). Moho offset across the northern margin of the Tibetan plateau. Science 281: 1 170-1 172 